\title{
Do the Federal Income Tax Deductions for Home Ownership Benefit the Less Advantage and Average American Family?
}

\author{
Praveen Das ${ }^{1}$, Denis Boudreaux ${ }^{1} \&$ S. P. Uma Rao ${ }^{1}$ \\ ${ }^{1}$ B. I. Moody III College of Business Administration, University of Louisiana at Lafayette, USA \\ Correspondence: Praveen Das, B. I. Moody III College of Business Administration, University of Louisiana at \\ Lafayette, USA \\ Received: January 29, 2017 \\ Accepted: October 16, 2017 \\ Online Published: October 18, 2017 \\ doi:10.5430/afr.v6n4p265 \\ URL: https://doi.org/10.5430/afr.v6n4p265
}

\begin{abstract}
Americans have traditionally placed a high worth on the ability of ordinary families to purchase a home. Even after the devastating financial crisis and the housing bubble in late 2008, according to the September 2014 Country Financial Security Index Survey, more than 89 percent of Americans rank buying a home among the top in achieving American Dream. The financial benefit arising out tax deductions available to homeowners has aided the less advantaged and middle class in achieving this American dream. A simulated model is shown for three families with large home price and income level differences to illustrate the relative economic gains from the federal current tax code to the three families.
\end{abstract}

Keywords: Mortgage interest, Tax deduction

\section{Introduction}

The American people have for a long time thought very favorably of the ability of ordinary families to purchase a home. In fact, homeownership is often viewed as the embodiment of the "American Dream." Homeownership is promoted by government policy using several means such as tax deductions for mortgage interest deduction, real estate tax, and excluding capital gains from the sale of homes. Many economists, politicians, and financiers view these subsidies for home ownership as providing critical assistance to the underprivileged and middle class in achieving this dream. In fact, nearly three times as many affluent individuals receive housing breaks as their less fortunate fellow Americans. It is also interesting that it is under a Republican Congress that such a tax incentive to the wealthy is being again considered for reform. The debate again revives over changing the tax code and the often-considered "sacred" cow of federal income tax deductions surrounding home ownership.

Mortgage lenders, real estate firms, home building contractor, and yes, even politicians have traditionally extolled the virtues of home ownership to middle-income Americans as well as the overall economy. It is well established that federal tax laws favor homeownership (Aaron, 1972) due to three tax deductions covering personal residences: (1) the mortgage interest; (2) state and local real estate taxes; and, (3) the ability to exclude capital gains from the sale of homes. Remarkable, it is estimated that these three provisions alone have resulted in total tax revenue losses of over $\$ 115$ billion for the fiscal year 2005. The Congressional Budget Office in February 2012, estimates that between 2013 and 2022, tax expenditures for the home mortgage interest deduction will grow to 0.8 percent of GDP.

The purpose of this research is to examine the present tax law covering home ownership with the primary focus being an investigation of the impact of the mortgage interest and related property income tax deductions on different levels of family income. An economic model will illustrate the financial benefits of these deductions to high, middle and low-income families. Additionally, a historical account of the capital gain exclusion on the sale of a residence will also be briefly presented.

1.1 An Overview of the Home Mortgage Interest Deduction, the Deduction of Property Taxes and the Capital Gain Exclusion

\subsubsection{Deduction of Property Taxes and Home Mortgage Interest Deduction}

In 1986, significant tax reform measures were passed that actually illuminated middle-class taxpayers from itemizing deductions unless they were homeowners. The estimated deductions for state and local property taxes for owner-occupied housing for 2015 was $\$ 19.19$ billion (U.S. Office of Management and Budget, 2016). The mortgage 
interest deduction (MID) essentially treats what should be considered as a personal expense as a business expense. For most homeowners, if qualified interest expense and property taxes plus other allowable deductions are more than the standard deduction, then it is to the taxpayer's advantage to file Schedule A. These tax benefits or subsidies were legislated to encourage home ownership and housing construction. However, with massive federal budget deficits and the common belief that these deductions favor the wealthy, they have become a target for elimination or at least significant reform and curtailment (President's Bush's 2005 Advisory Panel on Tax Reform).

The first major tax break passed to help homeowners were in the Revenue Act of 1951. There was no limit on the use of this provision during the taxpayer's lifetime. If residential property experienced price appreciation, a homeowner who uses financial leverage and continues to trade up in home prices without having to pay taxes on the gains could have achieved very significant returns. When replacing the sold home, the investor with financial leverage could have converted a large part of the profit or equity to cash and invested in other assets. To further alleviate the substantial tax liability that would be incurred by senior citizens when selling their homes, Congress enacted the Revenue Act of 1964 . Under the Act, the first $\$ 20,000$ of the gain by a taxpayer 55 or older were excluded from tax. Since 1964, the amount of the exclusion has been amended (increased) by subsequent tax acts.

Removed from the law are the requirements for the reinvestment of proceeds to avoid taxation of the gain as well as the special exclusion for taxpayers over 55. The exclusion is without regard to the age of the taxpayer and basically can be used by the taxpayer every two years. Included in the law are provisions for a partial exclusion if the two-year ownership and use test are not met.

\subsubsection{Justifications to Eliminate Tax Advantages for Home Ownership}

The cost of homeownership takes up a significant portion of the average family's total income. The purchase price, closing costs, maintenance expenses, property taxes, insurance and financing costs are some of the financial burdens of home ownership. When the tax-favored legislation was passed, home mortgage financing was not in sufficient supply and carried a high cost. In most cases, for a thirty-year traditional mortgage at moderate interest rates, the interest paid would exceed the actual amount borrowed by more than 2.5 times. Over the past twenty plus years, flexible mortgage financing instruments and funding institutions have become more available. The emergence of new avenues of financing has resulted in lowering financing costs. The relative cost of housing finance has been substantially reduced since the late 1980s (Vu, 1990). The extensive securitization of residential mortgages and the market acceptance of Adjustable Rate Residential Mortgages have diminished the sensitivity of housing activity to interest rate changes and materially reduced the financing burden. It is argued that because of the reduction in the relative cost of home financing, government tax policy and subsidizing are no longer needed to stimulate home ownership.

Justifications for the elimination of the subsidy also include the belief that the tax advantage unfairly favors home property and is economically inequitable to the renter. Besides the tax implications for the primary mortgage, homeowners can use second or equity mortgages to finance other asset purchases and pass the tax deduction on Schedule A of their tax returns. Homeowners using a second mortgage can get interest tax deductions on other purchases such as automobiles, vacations, boats, children's education costs, which of course renters cannot. The unfairness is magnified when home mortgage interest is substantial and the only deductible item. Some social economists opine that this deduction is the direct evidence of Director's Law - redistribution of income ultimately accrues to the median voter. Other economists purport that mortgage interest deductions subsidize homeowners at the expense of investments in other types of assets such as facilities and equipment. It can be argued that business investment and general economic activity is less and business debt financing costs are higher as a result of the MID. The basic federal tax schedule (like those of most states) is progressive, and the marginal tax rate goes up with the increase in income. The deductibility of mortgage interest and real estate taxes provides more substantial dollar advantage for tax reductions for the higher income families. Taking advantage of home ownership tax deductions by the income affluent can result in a decrease in the progressivity of the tax rate structure.

The Congressional Budget Office estimated that federal tax revenues would have increased by more than $\$ 42$ billion in 1998 if the MID had been eliminated. This increase would have continued at approximately the same amount each year after and would have helped to reduce the huge federal budget deficits and the need for federal government massive borrowing resulting in lower interest rates for consumers and businesses. Furthermore, some critics allege that the MID distorts consumer behavior and results in too large expenditure on housing and massive unjustified appreciation in prices. Some of the current housing crisis may be blamed on the MID. Others even blame the deterioration and plight of inner cities on the housing subsidy (Voith, 1999). With the MID, it is easier for middle class people to leave the inner cities and relocate in the suburbs. To the MID detractors, the deduction is view as a 
boondoggle that robs the treasury of billions and subsidizes America's wealthiest homeowners, the construction industry and even lending institutions such as Fannie Mae and Freddie Mac.

As illustrated in Tables, the Internal Revenue's Statistics of Income data for 2015 shows that the higher income bracket of the taxpayer, the greater is the utilization of both the mortgage interest deduction, the real estate tax deduction and all deductions. In fact, while individuals with incomes more than $\$ 200,000$ constitute only about 13.15 percent of all returns filed, these people account for 22.14 percent of the mortgage interest deduction returns.

Table 1. All Individual Income Tax Returns Filed by AG I and Mortgage Interest Deductions - 2014

\begin{tabular}{cccc}
\hline AGI & $\begin{array}{c}\text { \% of All Returns } \underline{\text { In }} \\
\text { Group }\end{array}$ & $\begin{array}{c}\text { \% of All Returns } \\
\text { With MID }\end{array}$ & $\begin{array}{c}\text { \% of Returns for Each Group With } \\
\text { MID }\end{array}$ \\
\hline Under $\$ 20,000$ & 4.93 & 2.72 & 51.90 \\
$\$ 20,000-\$ 39,999$ & 10.76 & 6.17 & 58.48 \\
$\$ 40,000-\$ 59,999$ & 14.17 & 9.87 & 70.00 \\
$\$ 60,000-\$ 99,999$ & 26.39 & 23.37 & 77.62 \\
$\$ 100,000-199,999$ & 30.61 & 35.72 & 82.11 \\
$\$ 200,000$ and Over & 13.15 & 22.14 & 76.50 \\
\hline
\end{tabular}

Table 2. All Individual Income Tax Returns that Paid Taxes Filed by AGI - 2014

\begin{tabular}{cccc}
\hline AGI & Returns In Group & $\begin{array}{c}\text { Estimated Returns } \\
\text { With Deductions }\end{array}$ & $\begin{array}{c}\text { \% of Returns }{ }^{1} \text { for } \\
\text { Each Group }\end{array}$ \\
\hline Under $\$ 20,000$ & $2,165,366$ & $1,504,402$ & 69.47 \\
$\$ 20,000-\$ 39,999$ & $4,729,817$ & $3,271,391$ & 69.17 \\
$\$ 40,000-\$ 59,999$ & $6,228,288$ & $4,903,840$ & 78.73 \\
$\$ 60,000-\$ 99,999$ & $11,603,488$ & $9,993,372$ & 86.12 \\
$\$ 100,000-199,999$ & $13,455,839$ & $12,289,055$ & 91.33 \\
$\$ 200,000$ and Over & $5,782,288$ & $5,358,482$ & 92.67
\end{tabular}

${ }^{1}$ There were over 5 million returns that were non-taxable. Most of the non-taxable returns most likely were for AGI of under $\$ 40,000$.

Table 3. Individual Income Tax Returns by AG I and Mortgage Interest Deductions for Returns Claiming the Deduction - 2014

\begin{tabular}{cccc}
\hline AGI & $\begin{array}{c}\text { (000's) Dollar } \\
\text { Amount of } \\
\text { Deduction }\end{array}$ & $\begin{array}{c}\text { Number Returns } \\
\text { for each Group } \\
\text { With MDI }\end{array}$ & $\begin{array}{c}\text { Average MID Deduction } \\
\text { Per Return }\end{array}$ \\
\hline Under \$20,000 & $7,812,449$ & $1,123,917$ & 6,951 \\
$\$ 20,000-\$ 39,999$ & $17,698,279$ & $2,766,195$ & 6,399 \\
$\$ 40,000-\$ 59,999$ & $28,305,695$ & $4,359,136$ & 6,494 \\
$\$ 60,000-\$ 99,999$ & $67,017,606$ & $9,007,136$ & 7,441 \\
$\$ 100,000-199,999$ & $102,421,078$ & $11,049,136$ & 9,270 \\
$\$ 200,000$ and Over & $63,493,911$ & $4,423,190$ & 14,355 \\
\hline
\end{tabular}


Table 4. Individual Income Tax Returns by AG I and Real Estate Taxes - 2014

\begin{tabular}{cccc}
\hline AGI & $\begin{array}{c}\text { (000's) Dollar } \\
\text { Amount of } \\
\text { Deduction }\end{array}$ & $\begin{array}{c}\text { Number of } \\
\text { Returns each } \\
\text { Group With } \\
\text { Deduction }\end{array}$ & $\begin{array}{c}\text { Average Deduction } \\
\text { Per Return }\end{array}$ \\
\hline Under \$ 20,000 & $5,680,776$ & $1,504,402$ & 3,777 \\
$\$ 20,000-\$ 39,999$ & $9,881,408$ & $3,271,391$ & 3,021 \\
$\$ 40,000-\$ 59,999$ & $15,056,436$ & $4,903,840$ & 3,071 \\
$\$ 60,000-\$ 99,999$ & $35,746,003$ & $9,993,372$ & 3,577 \\
$\$ 100,000-199,999$ & $60,011,175$ & $12,289,055$ & 4,883 \\
$\$ 200,000$ and Over & $54,659,894$ & $5,358,482$ & 10,201 \\
\hline
\end{tabular}

Table 5. Individual Income Tax Returns by AG I and Total Deductions for - 2014

\begin{tabular}{cccc}
\hline AGI & $\begin{array}{c}\text { (000’s) Dollar } \\
\text { Amount of } \\
\text { Deduction }\end{array}$ & $\begin{array}{c}\text { Estimated } \\
\text { Number of } \\
\text { Returns each } \\
\text { Group With }\end{array}$ & $\begin{array}{c}\text { Average Deduction } \\
\text { Per Return } \\
\text { Deduction }\end{array}$ \\
\hline Under \$ 20,000 & $34,335,736$ & $1,504,402$ & 22,830 \\
$\$ 20,000-\$ 39,999$ & $73,222,204$ & $3,271,391$ & 22,385 \\
$\$ 40,000-\$ 59,999$ & $103,075,554$ & $4,903,840$ & 21,023 \\
$\$ 60,000-\$ 99,999$ & $228,927,550$ & $9,993,372$ & 22,910 \\
$\$ 100,000-199,999$ & $344,438,245$ & $12,289,055$ & 28,028 \\
$\$ 200,000$ and Over & $422,705,795$ & $5,358,482$ & 78,892 \\
\hline
\end{tabular}

\subsubsection{Justifications To Preserve Tax Advantages For Home Ownership}

An important reason to maintain the deductibility of home mortgage interest as national policy is, is that the home loan constitutes the largest portion of a household's debt and the MID substantially reduces a family's financial burden of owning a home, thus improves the household's standard of living. The MID, a prominent component of the tax code, is the most used deduction following real estate taxes with 335 billion dollars was deducted by over 37 million taxpayers in 2004 (Internal Revenue, 2004). The MID is viewed as a cornerstone of American society because the deduction fosters home ownership as well as larger dollar investments in homes. Thus, a greater number of taxpayers can afford home ownership rather than renting, and some homeowners can afford higher valued properties because of the deductions. Homeownership theoretically provides externalities to society by giving individuals a stake in society, democracy, and neighborhoods. Furthermore, ownership encourages citizens to vote for long-run investments rather than short-run transfers. It is claimed that homeownership has positive outcomes for children and families. Other positive benefits accrue to home ownership. Home maintenance, upkeep, and gardening are also related to ownership. Research indicates that people are willing to pay more to live around homeowners as opposed to renters (Glaeser \& Shapiro, 2002). The use of second mortgages as a tax shelter allows for greater consumption as well as increased savings as a result of more disposable income. With the means to purchase more assets, a higher standard of living is attained. If the money saved through the tax shelter is not consumed, these dollars can be saved or invested in the capital markets.

Homeowners accumulate wealth through equity acquisition. In many cases, a person's home is their single most valuable asset and investment. The home becomes a repository of cash and wealth for future retirement. Because of existing tax provisions, most homeowners can sell their homes with, for the most part, the capital gains being tax-free. Home ownership is not only a way of life, but can also be a retirement investment that provides for a high return at low risk. 


\section{Methodology and Results}

This paper compares three possible homeowners who have significant differences in income, mortgage interest, and property taxes to determine how current tax laws influence -their tax savings. The assumptions are based on tax data for 2014 that include the following: Homeowner A has taxable income of \$50,000 without considering itemized deductions. This income level is the approximately the average household income from the Internal Revenue Service Statistics of Income for 2014. Homeowner B has taxable income of $\$ 100,000$ without considering itemized deductions from Schedule A, while Homeowner $C$ has an income of $\$ 500,000$. Homeowner A has a marginal tax rate of $15 \%$, B has a marginal tax rate of $25 \%$, and Homeowner B has a marginal tax rate of $35 \%$. Mortgage loans, property taxes, and other Schedule A deductions are functions of their income. It is assumed that the property taxes and other itemized deductions are proportional to taxpayer income and indebtedness. It is also assumed that all itemized deductions are subject to the high-income three percent cutback adjustment where appropriate and the home mortgage interest rate is 6 percent. The impact of the itemization of deductions for Taxpayers A and B is presented in Table 6.

Table 6. Family Tax Calculations When Itemizing Deductions: Mortgage Interest, Property Taxes and Other Deductions

(Dollars are in thousands)

\begin{tabular}{|c|c|c|c|}
\hline TAXPAYER/HOMEOWNER & $\underline{\mathbf{A}}$ & $\underline{\mathbf{B}}$ & $\underline{\mathbf{C}}$ \\
\hline $\begin{array}{l}\text { Taxable Income Without } \\
\text { Considering Itemized } \\
\text { Deductions }\end{array}$ & $\$ 50$ & $\$ 100$ & $\$ 500$ \\
\hline Marginal Tax Rate & $15 \%$ & $25 \%$ & $35 \%$ \\
\hline Home Mortgage Loan & $\$ 150$ & $\$ 300$ & $\$ 1,500$ \\
\hline $\begin{array}{l}\text { Maximum Indebtedness } \\
\text { Allowed Schedule A } \\
\text { Deductions: }\end{array}$ & $\$ 150$ & $\$ 300$ & $\$ 1,100$ \\
\hline Home Mortgage Interest $6 \%$ & $\$ 9$ & $\$ 18$ & $\$ 90$ \\
\hline Amount Allowed & $\$ 9$ & $\$ 18$ & $\$ 66$ \\
\hline Home Property Taxes & $\$ 3$ & $\$ 15$ & $\$ 75$ \\
\hline $\begin{array}{l}\text { Other Schedule A Deductions } \\
\text { Including Second Mortgages }\end{array}$ & $\$ 10$ & $\$ 10$ & $\$ 50$ \\
\hline $\begin{array}{l}\text { Total Itemized Deductions } \\
\text { Before 3\% Cutback Rule }\end{array}$ & $\$ 22$ & $\$ 43$ & $\$ 191$ \\
\hline $\begin{array}{l}\text { Total Itemized Deduction After } \\
\text { 3\% Cutback Rule }\end{array}$ & $\$ 22$ & $\$ 43$ & $\$ 184.128$ \\
\hline Standard Deduction 2007 & $\$ 12.4$ & $\$ 12.4$ & NA \\
\hline Deduction Over Standard & $\$ 9.6$ & $\$ 30.6$ & $\$ 184.128$ \\
\hline $\begin{array}{l}\text { Tax Benefit of Itemized } \\
\text { Deductions }\end{array}$ & $\$ 1.44$ & $\$ 7.65$ & $\$ 64.445$ \\
\hline Percentage Of Taxable Income & $2.88 \%$ & $7.65 \%$ & $12.89 \%$ \\
\hline
\end{tabular}

Table 6 shows the results of tax policy allowing the deduction of mortgage interest and real estate taxes in arriving at taxable income for the three hypothetical taxpayers. As can be seen, Taxpayer $\mathrm{C}$ has a greater tax benefit both concerning absolute magnitude $(\$ 64,445)$ and of saving as a percentage of disposable income $(12.89 \%)$. The preceding is true even when considering the three percent cutback on the itemized deductions of taxpayers with adjusted gross income in excess of $\$ 156,400$ for the year 2014 . Taxpayer B enjoys a tax benefit from the deductions of $\$ 7,650$, but at a lower percentage of income than $\mathrm{A}$ of $7.65 \%$. If the percentages can be viewed as a utility measure, it can be argued that a dollar saved by a family that has $\$ 500,000$ as taxable income has more dollar savings as well as the greater utility than the other taxpayers. Thus, concerning real consequences, the saving from home 
mortgage interest and property taxes may be more meaningful to the affluent class than the middle-class homeowners.

Homeowner A does not realize much of as much of a tax saving either in real dollars or as a percentage of income. The total tax deductions on Schedule A for the average taxpayer is $\$ 1,440$ and 2.88 percent of taxable income. Although not very large in comparison to the other income levels, it can be considered as meaningful. If the central argument in favor for maintaining the tax deductions for home mortgage interest and property tax is to help average households acquire home ownership by reducing the cost, then the premise is valid. Of the total amount of deductible expenses of $\$ 22,000$ for Homeowner A, $\$ 13,000$ is related to homeownership. If the home mortgage and property tax deductions were eliminated, Homeowner A would have to take the standard deduction and would pay $\$ 1,440$ more in income taxes.

Of the hundreds of tax subsidies in the Internal Revenue Code, some of the largest by far are those granted to homeowners. It was estimated by Congressional Joint Committee on Taxation that the mortgage interest deduction and the deduction for real estate taxes in 2006 cost the U.S. government over $\$ 90$ billion. As would be expected, these huge tax savings do not help lower-income taxpayers, but rather serve to subsidize high-income taxpayers with expensive homes and second homes.

Does this tax saving encourage more home acquisitions, result in other product consumption, and entice more personal savings? Possibly, but to which income group? Do these deductions contribute to a higher standard of living? Most likely, but this is a function of the individual taxpayer's income level; i.e., the higher the income level, the greater the benefit.

There is a high degree of passion in arguments on both sides of the tax code revision debates. It is easy to see why any changes or reforms have been slow in coming. There seems to be a degree of comfort with the "devil whom we know" and uneasiness with the devil "whom we do not know" in evaluating what is best when it comes to tax reforms.

With the current home mortgage troubles in the U.S., often referred to as the "Sub-Prime Mess," still in our rearview mirror and home ownership at a historic low, it is most likely that legislation that would cause the affordability of housing to decrease for any taxpayer will not be passed into law in the near future. The sacred cow, MID will continue to be, at least in the foreseeable future.

\section{References}

Aaron, Henry J. (1972). Shelter and Subsidies: Who Benefits from Federal Housing Policies? Brookings Institution.

Boudreaux, Philip, Denis Boudreaux, Dan Ward \& Suzanne Ward. (1997). Quantifying the Federal Income Tax Advantages Accruing to Home Purchase Rollover Strategies. ASBBS, Proceedings, 129-133.

Department of the Internal Revenue Service, Publication 936, Home Mortgage Interest Deduction, 2014, 2015 and 2016.

Follain, James R., Patric Hendershott, \& David C. (1987). Ling. Understanding the Real Estate Provisions of Tax Reform: Motivation and Impact. National Tax Journal, 40, 363-372.

Follain, James R. \& David C. Ling. (1991). The Federal Tax Subsidy to Housing and the Reduced Value of the Mortgage Interest Deduction. National Tax Journal, 44, 147-168.

Follain, James R., David C. Ling \& Gary A. McGill. (1993). The Preferential Income Tax Treatment of Owner-Occupied Housing: Who Really Benefits? Housing Policy Debate, 4, 1-24. https://doi.org/10.1080/10511482.1993.9521121

Follain, James R.,\& Lisa Sturman Melamed. (1998). The False Messiah of Tax Policy: What Elimination of the Home Mortgage Interest Deduction Promises and a Careful Look at What It Delivers. Journal of Housing Research 9(2), 179-199.

Glaeser, Edward L. \& Shapiro, Jesse M. (2002). The Benefits of the Home Mortgage Interest Deduction. Harvard Institute of Economic Research Paper, 1-61. https://doi.org/10.3386/w9284

Hu, Joseph. (1992). Housing and the Mortgage Securities Markets: Review, Outlook, and Policy Recommendations. Journal of Real Estate and Economics, 5,167-179. https://doi.org/10.1007/BF00221528

Internal Revenue Service, Statistics of Income Division. Publication 1304 August 2016. 
Joint Committee on Taxation. (2005). Estimates of Federal Tax Expenditures for Fiscal Years 2005 to 2009. JCS-105 U.S. Congress. P. 33. (2005).

Ling, David C. \& Gary A. McGill. (1992). Measuring the Size and Distributional Effects of Homeowner Tax Preferences. Journal of Housing Research, 3(2), 273-303.

Stansel, Dean \& Anthony Randazzo. (2011). Unmasking the Mortgage Interest Deduction: Who Benefits amd by How Much? Reason Foundation.

Taubman, Paul \& Robert Rasche. (1971). The Income Tax and Real Estate Investment. Tax Incentives, 113-142.

Tolley, George S. \& Douglas B. Diamond. (1977). Home Ownership, Rental Housing, and Tax Incentives. Federal Tax and Urban Development, 114-195.

U.S. Office Of Management and Budget. (2006) Budget of the United States Government, Analytical Perspectives, Fiscal Year 2006 Table 469.

Voith, Richard. (1999). Does the Federal Tax Treatment of Housing Affect the Pattern of Metropolitan Development? Federal Reserve Bank of Philadelphia Business Review, 3-16.

Woodward, Susan E., \& John C. (1989). Weicher. Goring the Wrong Ox: A Defense of the Home Mortgage Interest Deduction. National Tax Journal, 62, 301-313. 